\title{
Confirmation of Association Between ABO Blood Groups and Salivary ABH Secretor Phenotypes and Electrophoretic Patterns of Serum Alkaline Phosphatase
}

\author{
DAVID A. PRICE EVANS \\ From the Department of Medicine, University of Liverpool
}

Arfors, Beckman, and Lundin (1963), who had studied Swedish twin subjects, first pointed out that (I) serum alkaline phosphatases are present in either one or two electrophoretic bands which are under genetic control, (2) that their patterns are closely associated with the ABO blood groups in that the second electrophoretic alkaline phosphatase band is rarely found in adult subjects possessing an $A_{1}$ or an $A_{2}$ gene.

Beckman (1964) studied an extensive Brazilian family material comprising 468 adults and 839 children. It was found that all of them with an extra serum alkaline phosphatase band were secretors of $\mathrm{ABH}$ blood group substances. There was no correlation with secretion of Lewis substances. Only one adult of the 468 examined possessing an $A_{1}$ or $A_{2}$ gene showed two alkaline phosphatase bands; whereas over half the subjects of blood groups $\mathrm{O}$ and $\mathrm{B}$ showed this character.

Beckman (1964) concludes also that the family studies show that the appearance of the second electrophoretic alkaline phosphatase band is dependent on at least one additional factor besides the $\mathrm{ABO}$ and secretor genes.

The purpose of this communication is to confirm in the British population the associations described by Beckman (1964).

\section{Materials and Method}

Sera were from random British (white) blood transfusion volunteers.

Salivas were collected by having the subject spit into a test-tube. The quantity collected varied from $2 \cdot 0$ to $5.0 \mathrm{ml}$. Artificial stimuli to salivation were not employed. The specimens were boiled for to minutes on a water bath within an hour after collection, centrifuged

Received November 15, 1964. at about 2,000 r.p.m. for 5 minutes, and the supernatants were stored at $-20^{\circ} \mathrm{C}$. when not in use.

Starch was the hydrolysed variety for gel electro-phoresis from Connaught Medical Research Laboratories, University of Toronto, Canada.

Colouring agent. Fast Red TR salt (Gurr).

Electrophoresis. A gel was prepared by dissolving $24.2 \mathrm{~g}$. starch in $200 \mathrm{ml}$. of Tris- $\mathrm{HCl}$ buffer $0.05 \mathrm{M}, p \mathrm{H}$ 8.8. A $19 \mathrm{~cm}$. long horizontal gel was used, and during electrophoresis the gel and wicks were covered with $\bar{\partial}$ parafilm. The current was $20 \mathrm{~mA}$, voltage $260 \mathrm{~V}$, and the time $3 \frac{1}{2}$ hours. Electrophoresis was conducted $\frac{}{\Phi}$ at $+4^{\circ} \mathrm{C}$. In the electrode compartments Tris- $\mathrm{HCl} \varrho$ buffer $0.30 \mathrm{M}, p \mathrm{H} 8.6$ was used.

The sliced gel was stained for alkaline phosphatase 3 by incubation for one hour at $37^{\circ} \mathrm{C}$. with the following? modification of the technique of A. L. Latner (personalo communication, r964):

Io mg. sodium naphthyl phosphate (in $100 \mathrm{ml}$.

Io $\mathrm{mg}$. fast red TR salt

$20 \mathrm{mg}$. $\mathrm{MgCl}_{2} 6 \mathrm{H}_{2} \mathrm{O}$ $0.1 \mathrm{M}$ borate buffer $p \mathrm{H} 9 \cdot 6$. 3

During incubation the staining medium was renewed four times (to counteract the inhibition produced by $\frac{0}{3}$ the diazo-salt).

The second half of the sliced gel was stained with음 a saturated solution of Amido Black IOB in a mixture $D$ of methanol $200 \mathrm{ml}$., water $200 \mathrm{ml}$., glacial acetic을 acid $40 \mathrm{ml}$., to check upon the electrophoretic mobilities of serum protein bands.

ABO Blood Grouping. This was carried out by means of the standard tube techniques.

Determination of Salivary ABH Secretore Status. All salivas were tested for $\mathrm{H}, \mathrm{A}$, and B activity quantitatively by means of a doubling dilution? agglutination-inhibition technique with $0.145 \mathrm{M}$ sodium chloride as the diluent. Standard salivas from known $O, A$, and $B$ secretors and non-secretors were included ${ }_{\Omega}^{\mathbb{D}}$ in each day's estimations. 
TABLE

THE ELECTROPHORETICALLY DISTINGUISHED SERUM ALKALINE PHOSPHATASE BANDS IN HEALTHY BRITISH SUBJECTS OF KNOWN BLOOD GROUP AND SECRETOR PHENOTYPES

\begin{tabular}{|c|c|c|c|c|}
\hline \multirow{2}{*}{$\begin{array}{l}\text { Blood } \\
\text { Group }\end{array}$} & \multirow{2}{*}{$\begin{array}{c}\text { Salivary } \\
\text { ABH } \\
\text { Secretor } \\
\text { Status }\end{array}$} & \multicolumn{3}{|c|}{ Serum Alkaline Phosphatase Bands } \\
\hline & & $\begin{array}{l}\text { One } \\
\text { Band }\end{array}$ & $\begin{array}{l}\text { One Distinct Band and } \\
\text { a Faint Second Band }\end{array}$ & $\begin{array}{l}\text { Two } \\
\text { Distinct } \\
\text { Bands }\end{array}$ \\
\hline $\begin{array}{l}\text { O } \\
\text { O } \\
\text { A } \\
\text { A } \\
\text { B } \\
\text { B }\end{array}$ & $\begin{array}{l}\text { Secretor } \\
\text { Non-secretor } \\
\text { Secretor } \\
\text { Non-secretor } \\
\text { Secretor } \\
\text { Non-secretor }\end{array}$ & $\begin{array}{r}4 \\
12 \\
23 \\
7 \\
-\end{array}$ & $\frac{6}{-}$ & $\begin{array}{l}\frac{43}{E} \\
=\end{array}$ \\
\hline
\end{tabular}

\section{Discussion}

The results are shown in the Table and they show that the observations of Beckman (1964) are confirmed on a random sample of the British population.

The site of origin of the main alkaline phosphatase band which occurs in all subjects is the liver. The second band which occurs in some adult subjects only is derived from the jejunal mucosa (Hodson, Latner, and Raine, 1962; Cunningham and Rimer, 1963; Haije and De Jong, 1963). Very rarely healthy adults have a third band derived from bone.

In children the second (jejunal) band is more marked and in young children the bone band is commonly evident.

The cause of the variation in the intensity of the second band observed in the present experiment is not known. It could be merely technical or a variability due to environmental or genetic causes.
The findings of Arfors et al. (1963) and Beckman (1964), which are confirmed here, are to be considered very important as they represent a pleiotropism (two or more characters which are controlled by a single gene) at a biochemical level.

\section{Summary}

This short communication confirms in the British population results found previously on Swedes and Brazilians. Attention is hereby drawn to the association existing between ( $I$ ) electrophoretic serum and alkaline phosphatase bands and (2) the ABO blood group and salivary $\mathrm{ABH}$ secretor polymorphisms.

The author wishes to thank the following persons: Dr L. Beckman, The Institute of Medical Genetics, University of Uppsala, for the description of unpublished results; Mr W. T. A. Donohoe, Department of Medicine, University of Liverpool, for providing sera from healthy subjects of known blood group and secretor phenotype; and Miss R. Hillary for technical assistance.

\section{REFERENCES}

Arfors, K. E., Beckman, L., and Lundin, L. G. (1963). Genetic variations of human serum phosphatases. Acta genet. (Basel), $13,89$.

Beckman, L. (1964). Associations between human serum alkaline phosphatases and blood groups. ibid., 14, 286.

Cunningham, V. R., and Rimer, J. G. (I963). Isoenzymes of alkaline phosphatase of human serum. Biochem. F., 89, 50p.

Haije, W. G., and De Jong M. (1963). Iso-enzyme patterns of serum alkaline phosphatase in agar-gel electrophoresis and their clinical significance. Clin. chim. Acta, 8, 6r4.

Hodson, A. W., Latner, A. L., and Raine, L. (1962). Iso-enzymes of alkaline phosphatase. ibid., 7, 255 . 